\title{
SPESIASI DAN BIOAVAILABILITAS LOGAM BERAT DALAM SEDIMEN SUNGAI ROOMO GRESIK
}

\author{
I M. Siaka*, W. A. Rozin, dan K. G. D. Putra \\ Program Studi Kimia, Fakultas Matematika dan Ilmu Pengetahuan Alam, \\ Universitas Udayana, Jimbaran, Bali, Indonesia \\ *Email: made_siaka@unud.ac.id
}

\begin{abstract}
ABSTRAK
Aliran Sungai Roomo telah tercemar oleh bahan-bahan organik terutama dari limbah domestik dan industri.Cemaran logam berat juga dipastikan ada dalam sungai tersebut.Logam berat ini masuk ke dalam sedimen dan biota yang hidup di lingkungan tersebut dan dapat terakumulasi pada seluruh bagian tubuhnya.Tujuan penelitian ini adalah untuk menentukan tingkat pencemaran logam $\mathrm{Pb}, \mathrm{Cd}$, dan $\mathrm{Cu}$ dalam air dan sedimen Sungai Roomo Gresik serta menganalisis biovailabilitas logam berat tersebut.Metode ekstraksi bertahap dan digesti basah digunakan untuk melakukan spesiasi dan ekstraksi logam dari sedimen serta konsentrasi logamnya diukur menggunakan Spektrofotometer Serapan Atom (AAS). Kandungan logam Pb, Cd, dan $\mathrm{Cu}$ dalam aliran sungai Roomo Gresik telah melebihi batas yang diperbolehkan, yaitu berturut-turut 1,6038-7,8365 mg/L; 0,0251-0,0798 mg/L; dan 0,1709-0,2249 mg/L dalam air dan 213,7750-539,0763 $\mathrm{mg} / \mathrm{kg} ; 3,3467-39,7071 \mathrm{mg} / \mathrm{kg}$; dan 36,9168-190,7079 $\mathrm{mg} / \mathrm{kg}$ dalam sedimen. Pola spesiasi logam berat tersebut sebagai F1 atau fraksi EFLE (easily, freely, leachable, exchangeable), F2 (reducible), F3 (oxidisable), dan F4 (resistant) adalah sebagai berikut: F4 > F2 > F1 > F3 untuk Pb dan Cd, sedangkan Cu dengan pola F3 > F4 > F2 > F1. Logam Pb, Cd, dan $\mathrm{Cu}$ yang bioavailable berturut-turut 2,78-7,11\%, 1,98-20,44\%, dan 2,48$13,66 \%$, sementara yang berpotensi bioavailable berturut-turut 10,05-16,81\%; 9,41-54,44\%; dan 15,1894,19\%. Logam $\mathrm{Pb}, \mathrm{Cd}$, dan $\mathrm{Cu}$ yang non bioavailable berturut-turut 79,53-84,22\%, 25,11-86,04\%, dan 1,84$80,67 \%$. Dengan demikian, Sungai Roomo Gresik telah tergolong sebagai sungai yang tercemar.
\end{abstract}

Kata kunci: biavailabilitas, logam berat, sedimen, spesiasi, sungai

\begin{abstract}
The Roomo River Stream has been polluted by organic materials which were mainly from domestic and industrial waste. Heavy metals were also ensured contaminated the river. These heavy metals enter sediments and can accumulate in the biota living in the river. This study was aimed to determine the level of pollution of $\mathrm{Pb}, \mathrm{Cd}$, and $\mathrm{Cu}$ metals in the water and sediments of the Roomo Gresik River and to analyze the biovability of these heavy metals. The sequential extraction and wet digestion method were used to perform a speciation and extraction of the metals from sediments. The concentration of the metals was measured by the use of Atomic Absorption Spectrophotometer (AAS). The contents of $\mathrm{Pb}, \mathrm{Cd}$, and $\mathrm{Cu}$ metals in the river were exceeded the allowed limit, which were 1.6038-7.8365 mg/L; 0.0251-0.0798 mg/L; and 0.1709-0.2249 mg/L, respectively in water and $213.7750-539763 \mathrm{mg} / \mathrm{kg} ; 3.3467-39.7071 \mathrm{mg} / \mathrm{kg}$; and $36.9168-190.7079 \mathrm{mg} / \mathrm{kg}$, respectively in sediments. The pattern of heavy metal speciations as F1 or EFLE fraction (easily, freely, leachable, exchangeable), F2 (reducible), F3 (oxidizable), and F4 (resistant) were as follows: F4>F2>F1>F3 for Pb and $\mathrm{Cd}$, whereas $\mathrm{Cu}$ with the pattern of $\mathrm{F} 3>\mathrm{F} 4>\mathrm{F} 2>\mathrm{F} 1$. The percentages of bioavailability of $\mathrm{Pb}, \mathrm{Cd}$, and $\mathrm{Cu}$ metals including readily biavailable were $2.78-7.11 \%, 1.98-20.44 \%$, and $2.48-13.66 \%$, potentially bioavailable were $10.05-16.81 \%, 9.41-54.44 \%$, and $15.18-94.19 \%$. Non-bioavailable were $79.53-84.22 \%, 25.11-86.04 \%$ and $1.84-$ $80.67 \%$, respectively. Therefore, the Roomo Gresik River has been classified as a polluted river.
\end{abstract}

Keywords: bioavailability, heavy metals, river, sediment, speciation

\section{PENDAHULUAN}

Air merupakan unsur utama dalam kehidupan manusia yang tidak dapat digantikan oleh senyawa lain. Beraneka ragam aktivitas bisa dilakukan di suatu perairan, mulai dari menangkap ikan, mandi, mencuci, dan bahkan kegiatan untuk industri. Kegiatan ini tentunya 
dapat membawa dampak pencemaran bagi lingkungan sekitarnya apabila limbahnya langsung bermuara ke perairan tanpa proses pengolahan yang baik (Zulfitri, 1998).

Spesiasi merupakan suatu pendekatan yang dilakukan untuk penentuan konsentrasi logam dalam berbagai bentuk ikatannya sebagai spesies yang membentuk konsentrasi total dalam suatu sampel (Pascoli, 1999). Sementara itu, bioavailabilitas adalah ketersediaan logam yang diserap oleh hayati, sehingga dapat mengubah sifat fisik dan dapat memunculkan efek toksik (Bernard and Neff, 2001). Spesiasi logam berat dalam media lingkungan (air, tanah, dan sedimen) dapat menjadi dasarpenentuan bioavailabilitasnya. Dengan demikian, penelitian spesiasi dan bioavailabiltas memiliki keterkaitan, yakni penelitian spesiasi dapat digunakan untuk memperkirakan bioavailabilitas pada suatu komponen perairan.

Menurut Darmono (1995), logam berat seperti $\mathrm{Pb}, \mathrm{Cd}$, dan $\mathrm{Cu}$ adalah logam yang berbahaya dan dapat masuk ke dalam tubuh melalui berbagai jalur, yaitu saluran pernafasan, pencernaan (usus, hati, ginjal) dan juga melalui kulit (Ma'ruf, 2007). Logam berat yang masuk ke tubuh makhluk hidup adalah logam yang bioavailable yang keberadaannya sebagai spesies yang tersedia. Logam $\mathrm{Pb}, \mathrm{Cd}$, dan $\mathrm{Cu}$ masuk ke dalam golongan pencemar karena logam tersebut memiliki sifat yang tidak dapat terurai dan mudah terabsorbsi. Dalam perairan umumnya logam berat membutuhkan perhatian khusus karena dapat memberikan pengaruh buruk bagi kesehatan manusia jika terakumulasi dalam tubuh organisme yang masuk ke dalam rantai makanan.

Sungai Roomo merupakan salah satu saluran drainase yang memiliki panjang aliran 2.987 meter yang melintasi kawasan industri, tempat pembuangan sampah, dan pemukiman warga. Keberadaan sungai ini menjadi sangat penting karena masyarakat banyak memanfaatkan airnya untuk mengairi tambak dan perkebunan milik mereka. Salah satu pencemar yang berpotensi masuk kedalam sistem perairan Sungai Roomo adalah komponen anorganik, terutama adalah logam berat $\mathrm{Pb}, \mathrm{Cd}$, dan $\mathrm{Cu}$ yang dihasilkan oleh salah satu industri agrokimia terbesar di Indonesia, yaitu PT Petrokimia Gresik. Oleh karena aliran sungai ini melintasi kawasan industri dan tempat pembuangan sampah, maka Sungai Roomo berpotensi mengalami pencemaran logam $\mathrm{Pb}$, $\mathrm{Cd}$, dan $\mathrm{Cu}$.

Pada penelitian ini dilakukan analisis kandungan logam $\mathrm{Pb}, \mathrm{Cd}$ dan $\mathrm{Cu}$ total, spesiasi dan bioavailabilitas logam tersebut dalam sedimen Sungai Roomo Gresik.

\section{MATERI DAN METODE}

\section{Bahan}

Bahan-bahan yang digunakan dalam penelitian ini adalah sampel air sungai, sedimen, $\mathrm{NH}_{2} \mathrm{OH}$. $\mathrm{HCl}, \quad \mathrm{CH}_{3} \mathrm{COONH}_{4}, \mathrm{H}_{2} \mathrm{O}_{2}$, $\mathrm{HNO}_{3}$ pekat, $\mathrm{HCl}$ pekat, $\mathrm{Pb}\left(\mathrm{NO}_{3}\right)_{2}, \mathrm{Cd}\left(\mathrm{NO}_{3}\right)_{2}$, $\mathrm{CuSO}_{4} .5 \mathrm{H}_{2} \mathrm{O}$, dan akuades.

Alat

Peralatan yang digunakan dalam penelitian ini adalah kantong plastik, labu ukur, pipet volume, gelas ukur, gelas beaker, shaker (penggojog listrik), ultrasonic bath, kertas saring Whatman 42, neraca analitik, oven, ayakan 63 $\mu \mathrm{m}, \mathrm{pH}$ meter, hotplate, dan AAS (Atomic Absorption Spectrophotometer) Shimadzu AA7000 .

\section{Lokasi Pengambilan Sampel}

Sampel diambil di 6 titik secara acak dari hulu ke hilir di saluran Sungai Roomo yang memiliki panjang 2.987 meter. Pemilihan titik sampling inidilakukan berdasarkan titik aktivitas yang terjadi di sepanjang aliran sungai.Penomoran sampel dimulai dari arah selatan ke utara atau dari hulu ke hilir. Titik I:

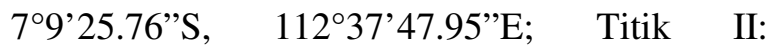
7०9'6.6”'S, 112 38'2.49"E; Titik III: 7०8'57.05"S, $112^{\circ} 37^{\prime} 40.34$ 'E; Titik IV: 7 8 '44.01”S, $112^{\circ} 37$ '55.55"E; Titik V: 7०8'24.78”S, $112^{\circ} 37^{\prime} 41.33$ ”'E; Titik VI: 7०7'59.95”'S, 112³7’0.76”E (Sumber: Aplikasi GPS \& Maps). Dengan keterangan Lokasi sebagai berikut: 1. Pintu Masuk Kawasan Industri Gresik; 2.Tempat Pembuangan Akhir (TPA) Ngipik; 3. Saluran Pembuangan PT. Petrowidada; 4. Saluran Drainase Kawasan Terpadu PT.SMELTING; 5. Pemukiman Desa Roomo; 6. Muara Kali Roomo. 


\section{Cara Kerja}

Pengambilan Sampel Sedimen

Sampel diambil di 6 titik secara acak dari hulu ke hilir di aliran Sungai Roomo (Gb. 1). Sebelum air diambil, terlebih dahulu diukur pHnya. Sampel air yang telah diambil ditambah $\mathrm{HNO}_{3}$ pekat sehingga pHnya tidak lebih dari 2 kemudian disimpan dalam botol polietilen. Sampel sedimen diambil pada kedalaman \pm 30 $\mathrm{cm}$ dari permukaan sedimen sebanyak $500 \mathrm{~g}$ pada masing- masing titik. Sampel langsung diayak dengan ayakan berukuran $63 \mu \mathrm{m}$ di tempat dengan bantuan air sungai di lokasi pengambilan sampel. Setelah diayak, sampel dimasukkan ke dalam plastk polietilen dan selanjutnya disimpan di dalam coolbox. Pengambilan sampel dilakukan pengulangan sebanyak 3 kali.

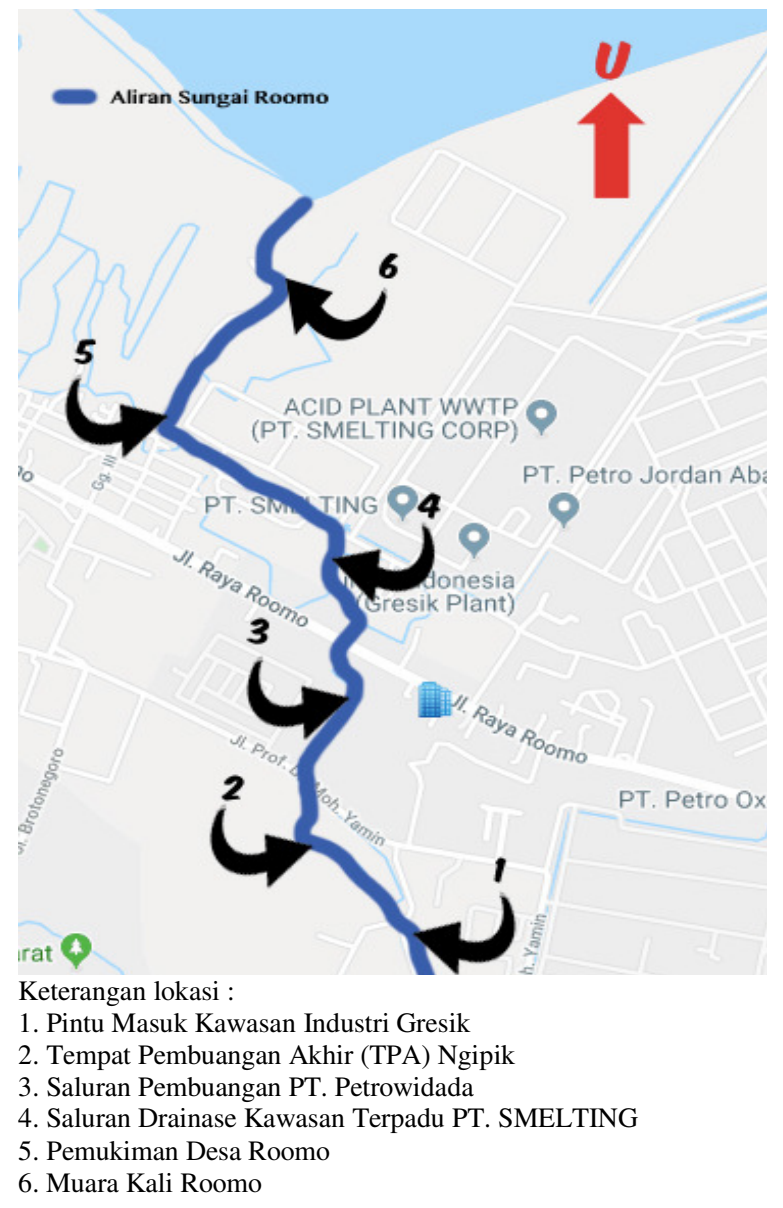

Gambar 1. Peta lokasi Samling

\section{Preparasi Sampel Sedimen}

Sedimen yang masih tercampur dengan air sungai diendapkan hingga endapannya terpisah. Endapan dikeringkan dalam oven pada suhu tidak lebih dari $60^{\circ} \mathrm{C}$ hinggakering (berat konstan).

\section{Penentuan Konsentrasi $\mathrm{Pb}, \mathrm{Cd}$, dan $\mathrm{Cu}$ Total Dalam Sedimen}

Sebanyak $1 \mathrm{~g}$ sampel sedimen dimasukkan ke dalam gelas beaker, ditambah 10 $\mathrm{mL}$ larutan reverse aquaregia (campuran $\mathrm{HCl}$ pekat dan $\mathrm{HNO}_{3}$ pekat (1:3)). Selanjutnya campuran tersebut didigesti dalam ultrasonic bath pada suhu $60^{\circ} \mathrm{C}$ selama 45 menit. Digesti dilanjutkan dengan memanaskan larutan tersebut pada hotplate selama 45 menit dengan suhu $140^{\circ} \mathrm{C}$. Larutan hasil digesti disentrifugasi, filtrat yang diperoleh disaring dan diencerkan dengan aquades pada labu ukur $25 \mathrm{~mL}$ hingga tanda batas. Larutan ini kemudian disaring dan diukur dengan AAS(Siakaet al.,1998).

\section{Spesiasi Logam $\mathrm{Pb}, \mathrm{Cd}$ dan $\mathrm{Cu}$ Ekstraksi tahap 1 (fraksi EFLE)}

Sebanyak $2 \mathrm{~g}$ sampel sedimen ditambahkan $25 \mathrm{~mL} \mathrm{CH} \mathrm{CH}_{3} \mathrm{COOH} \mathrm{0,1} \mathrm{M} \mathrm{(pH} \mathrm{7),}$ digojog selama 3 jam dengan shaker. Selanjutnya, disentrifugasi dan supernatannya didekantasi dan disaring. Supernatan dimasukkan ke dalam labu ukur $50 \mathrm{~mL}$ dan diencerkan dengan aquades hingga tanda batas. Logam $\mathrm{Pb}$, $\mathrm{Cd}$, dan $\mathrm{Cu}$ dalam filtrat diukur dengan AAS pada panjang gelombang $217,0 \mathrm{~nm}$ untuk $\mathrm{Pb}$, $228.8 \mathrm{~nm}$ untuk $\mathrm{Cd}$ dan $324,7 \mathrm{~nm}$ untuk $\mathrm{Cu}$.

\section{Ekstraksi tahap 2 (fraksi tereduksi asam atau fraksi Fe-Mn oksida)}

Residu dari tahap 1 dicuci dengan $10 \mathrm{~mL}$ akuades. Kemudian ditambah $40 \mathrm{~mL}$ $\mathrm{NH}_{2} \mathrm{OH} . \mathrm{HCl} 0,1 \mathrm{M}$, diatur pada $\mathrm{pH} 2$ dengan menambahkan $\mathrm{HNO}_{3}$ dan digojog selama 3 jam dengan shaker, kemudian disentrifugasi dan disaring. Filtratnya diencerkan dengan aquades dalam labu ukur $50 \mathrm{~mL}$ hingga tanda batas dan dianalisis dengan AAS pada panjang gelombang 217,0 nm untuk $\mathrm{Pb}, 228.8 \mathrm{~nm}$ untuk Cd dan324,7 $\mathrm{nm}$ untuk $\mathrm{Cu}$. Residu yang dihasilkan dari fraksi ini kemudian digunakan untuk ekstraksi selanjutnya.

\section{Ekstraksi tahap 3 (fraksi oxidisable)}

Residu tahap 2 dicuci dengan $10 \mathrm{~mL}$ akuades. Kemudian, ditambah $10 \mathrm{~mL}$ larutan $\mathrm{H}_{2} \mathrm{O}_{2}$ 8,8 $\mathrm{M}$ dan dipanaskan dalam penangas air pada suhu $85^{\circ} \mathrm{C}$. Campuran tersebut kemudian ditambah $20 \mathrm{~mL}$ larutan $\mathrm{CH}_{3} \mathrm{COONH}_{4} 1 \mathrm{M}$, diatur sehingga pHnya 2 dengan menambahkan 
$\mathrm{HNO}_{3}$, kemudian digojog selama 3 jam lalu disentrifugasi dan disaring. Filtrat diencerkan dengan aquades dalam labu ukur $50 \mathrm{~mL}$ hingga tanda batas, lalu logam $\mathrm{Pb}, \mathrm{Cd}$, dan $\mathrm{Cu}$ diukur dengan AAS pada panjang gelombang 217,0 nm untuk $\mathrm{Pb}, 228.8 \mathrm{~nm}$ untuk $\mathrm{Cd}$ dan $324,7 \mathrm{~nm}$ untuk $\mathrm{Cu}$. Residu digunakan untuk ekstraksi selanjutnya.

\section{Ekstraksi tahap 4 (fraksi resistant)}

Residu tahap 3 dicuci dengan $10 \mathrm{~mL}$ akuades kemudian ditambah $10 \mathrm{~mL}$ larutan reverse aquaregia, campuran tersebut didigesti dalam ultrasonic bath pada suhu $60^{\circ} \mathrm{C}$ selama 45 menit. Digesti dilanjutkan dengan memanaskanlarutan di atas hotplate selama 45 menit dengan suhu $140^{\circ} \mathrm{C}$. Larutan hasil digesti disentrifugasi dan disaring, kemudian filtrat yang diperoleh diencerkan dengan akuades dalam labu ukur $50 \mathrm{~mL}$ hingga tanda batas. Larutan ini kemudian diukur dengan AAS pada panjang gelombang 217,0 nm untuk $\mathrm{Pb}, 228.8 \mathrm{~nm}$ untuk $\mathrm{Cd}$ dan 324,7 nm untuk Cu.. Pada tahap ini diperoleh logam $\mathrm{Pb}, \mathrm{Cd}$ dan $\mathrm{Cu}$ yang bersifat resistant.

\section{HASIL DAN PEMBAHASAN}

\section{Kandungan Logam $\mathrm{Pb}, \mathrm{Cd}$, dan $\mathrm{Cu}$ dalam Air Sungai}

Logam $\mathrm{Pb}, \mathrm{Cd}$, dan $\mathrm{Cu}$ hasil pengukuran denga AAS ditentukan menggunakan metode kurva kalibrasi. Persamaan regresi linier dari kurva kalibrasi logam $\mathrm{Pb}$ yaitu y $=0,0361 \mathrm{x}+$ 0,0051 dengan Koefisien Regresi (R) sebesar 0,9998 . Untuk logam Cd yaitu $\mathrm{y}=0,3443 \mathrm{x}-$ 0,0047 dengan Koefisien Regresi (R) sebesar 0,9998 dan untuk logam $\mathrm{Cu}$ yaitu $\mathrm{y}=0,0501 \mathrm{x}-$ 0,0079 dengan Koefisien Regresi (R) sebesar 0,9948 . Hasil koefisien regresi linier (R) dari logam $\mathrm{Pb}, \mathrm{Cd}$, dan $\mathrm{Cu}$ menunjukkan linearitas kurva kalibrasi yang baik dan valid karena memiliki nilai $\mathrm{R} \geq 0$ 0.99.Persamaan regresi linier ketiga logam tersebut digunakan untuk menentukan konsentrasi logam dalam air sungai dan disajikan pada Tabel 1.

Menurut Peraturan Pemerintah No. 82 Tahun 2001tentang pengelolaan kualitas air dan pengendalian pencemaran air, ambang batas kandungan logam $\mathrm{Pb}$ dalam perairan adalah 0,03 $\mathrm{mg} / \mathrm{L}, \operatorname{logam} \mathrm{Cd}$ adalah $0,01 \mathrm{mg} / \mathrm{L}$ dan $\operatorname{logam} \mathrm{Cu}$ sebesar $0,02 \mathrm{mg} / \mathrm{L}$. Dari data yang tertera pada Tabel 1terlihat bahwa kandungan logam $\mathrm{Pb}, \mathrm{Cd}$ dan $\mathrm{Cu}$ dalam air Sungai Roomo di keenam titik sampling telah melebihi ambang batas yang diperbolehkan. Tidak terkecuali pada lokasi 6

Tabel 1. Kandungan Logam $\mathrm{Pb}, \mathrm{Cd}$, dan $\mathrm{Cu}$ Dalam Air Sungai Roomo

\begin{tabular}{cccc}
\hline $\mathrm{L}$ & {$[\mathrm{Pb}](\mathrm{mg} / \mathrm{L})$} & {$[\mathrm{Cd}](\mathrm{mg} / \mathrm{L})$} & {$[\mathrm{Cu}](\mathrm{mg} / \mathrm{L})$} \\
\hline \multirow{2}{*}{1} & 1,6038 & 0,0299 & 0,1736 \\
& \pm 0.0278 & \pm 0.0010 & \pm 0.0040 \\
2 & 2,1828 & 0,0258 & 0,1709 \\
& \pm 0.0182 & \pm 0.0006 & \pm 0.0031 \\
3 & 2,4913 & 0,0258 & 0,1896 \\
& \pm 0.0125 & \pm 0.0006 & \pm 0.0020 \\
4 & 2,6122 & 0,0298 & 0,1876 \\
& \pm 0.0454 & \pm 0.0045 & \pm 0.0053 \\
5 & 7,8365 & 0,0798 & 0,2249 \\
& \pm 0.1108 & \pm 0.0011 & \pm 0.0050 \\
6 & 3,3905 & 0,0637 & 0,1749 \\
& \pm 0.0980 & \pm 0.0010 & \pm 0.0031 \\
\hline
\end{tabular}

L: Lokasi

yang notabene berada di dekat muara sungai yang memiliki arus yang cukup deras.Kandungan logam $\mathrm{Pb}, \mathrm{Cd}$, dan $\mathrm{Cu}$ yang tertinggi berada pada titik sampling 5. Hal ini kemungkinan disebabkan karena lokasi 5 ini alirannya melalui pemukiman warga yangsaluran pembuangan limbahnya mengalir melalui lokasi sampling ini dan merupakan titik pertemuan dari percabangan beberapa saluran pembuangan air yang lain, sehingga dimungkinkan terdapat tambahan limbah domestik yang dihasilkan dari aktivitas warga sekitar. Selain itu aliran air di lokasi 5 tidak begitu deras dan di tepian sungainyabanyak terdapat tanaman sehingga air yang mengandung logam $\mathrm{Pb}, \mathrm{Cd}$, dan $\mathrm{Cu}$ lebih lama tertahan di lokasi ini.

Kandungan logam $\mathrm{Pb}$ terendah berada pada lokasi 1. Hal ini disebabkan karena lokasi 1 belum memasuki kawasan industri sehingga logam yang terkandung jumlahnya belum tinggi karena hanya berasal dari limbah domestik dan kegiatan perdagangan yang dilakukan oleh masyarakat di sekitarnya. Kandungan logam $\mathrm{Cd}$ dan $\mathrm{Cu}$ terendah berada pada lokasi 2. Lokasi ini melalui tempat pembuangan sampah akhir (TPA). Kandungan logamnya relatif rendah, kemungkinan disebabkan karena pengelolaan sampah yang dilakukan oleh pengelola cukup baik sehingga air lindi, yaitu cairan yang merembes melalui tumpukan sampah dengan membawa materi terlarut atau tersuspensi terutama hasil proses dekomposisi materi sampah (Damanhuri, 2010) yang dihasilkan oleh 
TPA tersebut tidak banyak meresap ke dalam air tanah dan sungai. Selain itu di lokasi TPA tersebut dilakukan pengelolaan air sebelum dibuang ke perairan. Kandungan logam yang terendah dari ketiga logam yang diamati adalah logam Cd. Kandungan logam Cd yang rendah dalam aliran Sungai Roomodikarenakan jumlah cemaran logam $\mathrm{Cd}$ yang lebih sedikit dibandingkan logam $\mathrm{Pb}$ dan $\mathrm{Cu}$. Kandungan logam $\mathrm{Pb}$ dalam air Sungai Roomo menempati posisi tertinggi diantara logam lainnya karena sumber cemaran logam $\mathrm{Pb}$ terdapat di sepanjang aliran sungai, mulai dari gas residu kendaraan bermotor dan mesin pabrik hingga kandungan dalam limbahnya yang dialirkan ke laut melalui Sungai Roomo.

\section{Kandungan Logam $\mathrm{Pb}$, Cd, dan $\mathrm{Cu}$ Total dalam Sedimen}

Kandungan logam $\mathrm{Pb}, \mathrm{Cd}$, dan $\mathrm{Cu}$ total dalam sedimen ditunjukkan pada Tabel 2 . Konsentrasi logam $\mathrm{Pb}$ dalam sedimen Sungai Roomo berkisar 213,7750-539,0763 mg/kg. Kandungan logam $\mathrm{Pb}$ tertinggi ditemukan pada lokasi 5 sedangakanyang terendah berada pada lokasi 2. Lokasi 5 merupakan lokasi aliran sungai yang dekat dengan pemukiman Desa Roomo. Ini menunjukkan bahwa sumber pencemaran $\mathrm{Pb}$ lebih banyak berasal dari limbah pemukiman yang ada di sepanjang aliran sungai tersebut. Disamping itu, lokasi 5 merupakan lokasi dekat dengan hilir yang sedimennya cendrung menampung atau mengendapkan cemaran yang berasal dari hulu sungai. Tingginya cemaran logam $\mathrm{Pb}$ dalam sedimen perairan tersebut tidak terlepas dari buangan limbah industri-industri yang ada di sebelah hulu kawasan aliran Sungai Roomo. Lu (1995) menyatakan bahwa logam $\mathrm{Pb}$ cukup besar terdeteksi di kawasan industri. Jika diurutkan berdasarkan besaran kadarnya, di posisi kedua terdapat logam $\mathrm{Cu}$ yang berkisar antara $36,9168-190,7079 \mathrm{mg} / \mathrm{kg}$ dan pada posisi terakhir adalah logam $\mathrm{Cd}$ yang jumlahnya berkisar antara 3,3467-39,7071 $\mathrm{mg} / \mathrm{kg}$. Keberadaan logam $\mathrm{Cd}$ dan $\mathrm{Cu}$ di perairan, terutama dalam sedimennya merupakan akumulasi cemaran dari buangan limbah masyarakat dan pabrik yang ada di sepanjang aliran sungai tersebut. Selain itu, masuknya logam berat tersebut ke dalam tatanan lingkungan bisa bersumber dari peristiwa secara

Tabel 2.Kandungan Logam $\mathrm{Pb}, \mathrm{Cd}$ dan $\mathrm{Cu}$ Total dalam Sedimen

\begin{tabular}{cccc}
\hline $\mathrm{L}$ & {$[\mathrm{Pb}](\mathrm{mg} / \mathrm{kg})$} & {$[\mathrm{Cd}](\mathrm{mg} / \mathrm{kg})$} & {$[\mathrm{Cu}](\mathrm{mg} / \mathrm{kg})$} \\
\hline \multirow{2}{*}{1} & 215,1749 & 10,5740 & 119,1346 \\
& $\pm 0,2793$ & $\pm 0,3511$ & $\pm 0,3281$ \\
2 & 213,7750 & 16,4519 & 117,8406 \\
& $\pm 0,2685$ & $\pm 0,0373$ & $\pm 0,2435$ \\
3 & 249,3471 & 17,2489 & 190,7079 \\
& $\pm 1,5294$ & $\pm 0,0504$ & $\pm 0,4504$ \\
4 & 301,5762 & 3,3467 & 36,9168 \\
& $\pm 0,5197$ & $\pm 0,0245$ & $\pm 0,3983$ \\
5 & 539,0763 & 26,9186 & 100,2847 \\
& $\pm 0,5224$ & $\pm 0,0538$ & $\pm 0,5387$ \\
6 & 348,0612 & 39,7071 & 104,9895 \\
& $\pm 0,4358$ & $\pm 0,0459$ & $\pm 0,8373$ \\
\hline
\end{tabular}

L: Lokasi

alami di dalam perairan (Suryati, 2011).Kandungan logam berat yang ditemukan di sepanjang aliran Sungai Roomo sudah melebihi ambang batas yang ditetapkan oleh Australian and New Zealand Environment and Conservation Council (ANZECC, 2000),dimana kadar logam berat yang dapat menyebabkan efek biologis terhadap lingkungan adalah $50 \mathrm{mg} / \mathrm{kg}$ berat keringuntuk logam $\mathrm{Pb}, 65 \mathrm{mg} / \mathrm{kg}$ berat kering untuk logam $\mathrm{Cu}$, dan $1,5 \mathrm{mg} / \mathrm{kg}$ berat kering untuk logam $\mathrm{Cd}$.

Jika dilihat perbandingan kadarnya di dalam sedimen dan air, maka kadar logam berat dalam sedimen jauh lebih besar jumlahnya. Hal ini disebabkan karena masuknya logam berat ke dalam badan air dan mengendap di dalam sedimen terjadi akibat tiga tahap, yaitu adanya curah hujan, adsorpsi, dan penyerapan oleh organisme air. Logam berat dalam perairan biasanya akan diserap oleh partikel dan terakumulasi di dalam sedimen. Ini terjadi dikarenakan logam berat memiliki sifat mengikat bahan-bahan organik dan partikel lainnya sehingga akan mengendap di dasar dan menyatu dengan sedimen yang lain (Fajri, 2001). 


\section{Spesiasi dan bioavailabilitas logam $\mathbf{P b}, \mathrm{Cd}$, dan Cu dalam Sedimen}

Penentuan spesiasi dan bioavailabilitas logam $\mathrm{Pb}, \mathrm{Cd}$, dan $\mathrm{Cu}$ dapat dilakukan dengan metode ekstraksi bertahap. Berdasarkan spesiesspesies logam tersebut, maka logam-logam yang bioavailable, berpotensi bioavailable, dan non bioavailabledapat ditentukan. Bioavailabilitas logam berat $\mathrm{Pb}, \mathrm{Cd}$, dan $\mathrm{Cu}$ dapat dilihat dari spesies - spesies logam yang berasosiasi pada fase masing - masing fraksinya. Logam yang berada pada fraksi 1 (EFLE) merupakan logam yang bioavailable, logam yang berada pada fraksi 2 dan 3 merupakan logam yang berpotensi bioavailable, dan logam yang berada pada fraksi 4 (resistant) merupakan logam yang tidak bioavailable.Hasil dari tahapan-tahapan tersebut berupa konsentrasi masing-masing fraksi yang kemudian dijumlahkan untuk menghitung konsentrasi total dan selanjutnya dapat digunakan untuk menentukan persentase logam terekstraksi dari setiap fraksi. Persentase logam berat setiap fraksi disajikan pada Gambar 2-5. Tahapan pertama pada proses ekstraksi bertahap ini untuk menentukan logam yang bersifat mudah lepas, bebas, mudah terkikis dan dapat dipertukarkan atau juga disebut fraksi EFLE (easily, freely, leachable, and exchangeable). Ektraksi pada tahap pertama ini merupakan fraksi yang memiliki ikatan paling labil seperti ikatan ion, ikatan karbonat, ikatan kompleks ion dan ikatan yang dapat tertukarkan. Logam berat pada fraksimerupakan logam yang bioavailable dan bisa tergolong berbahaya bagi lingkungan sekitarnya.

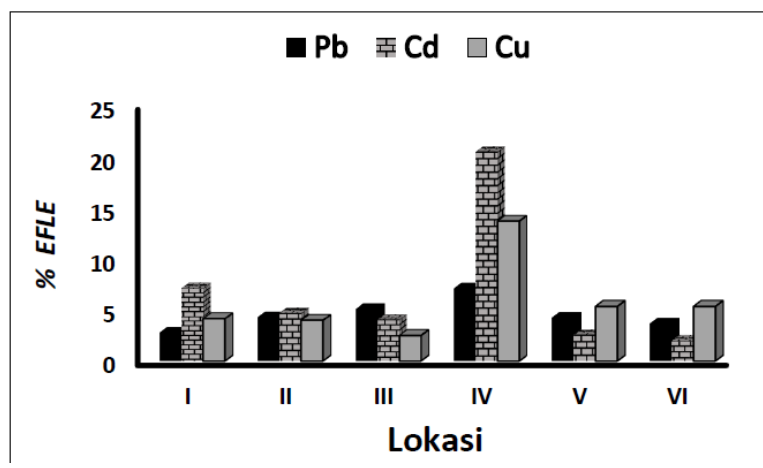

Gambar 2. Fraksi EFLE dalam sedimen
Persentase logam $\mathrm{Pb}, \mathrm{Cd}$, dan $\mathrm{Cu}$ yang berasosiasi pada fraksi EFLE ini kurang $<10 \%$ dari logam totalnya kecuali, di lokasi IV yaitu 20,44\% untuk $\mathrm{Cd}$ dan $13,66 \%$ untuk $\mathrm{Cu}$ (seperti terlihat pad Gb.1). Dengan relatif rendahnya keberadaan logam berat yang bioavaliabledalam sedimen di sepanjang aliran Sungai Roomo, maka dapat diharapkan bahwa organisme dan tumbuhan air yang ada di sungai ini relatif aman dari kontaminasi logam-logam berat tersebut. Walaupun kita tahu bahwalogam-logam yang ada pada fraksi ini sertamertadapat diserap oleh organisme yang hidup di perairan tersebut, baik hewan akuatik maupun tumbuh-tumbuhan.

Fraksi pada tahapan ekstraksi yang kedua merupakan fraksi reducible. Fraksi reducibleini merupakan fraksi yang menunjukkan bahwa logam berikatan atau berasosiasi dengan Fe-Mn oksida dan dapat direduksi oleh asam pada kondisi redoks tertentu (Gasparatos dkk., 2005), sehingga logam lepas menjadi ion atau ion molekul. Fraksi inimerupakan fraksi yang berpotensi bioavailable dan dapat berubah menjadi bioavailable jika di reduksi oleh asam atau reduktor kuat. Logam - logam yang berasosiasi pada fraksi ini cenderung lebih stabil daripada logam-logam pada fraksi EFLE. Persentase logam $\mathrm{Pb}$ yang berasosiasi dengan Fe-Mn oksida ini berkisar 7,27 - 12.24\% dari logam totalnya, sedangkan untuk logam $\mathrm{Cd}$ dan $\mathrm{Cu}$ berturut-turut berkisar antara 5,85-35,42\% dan 4,07-25,23\% dari logam totalnya (Gb. 3).

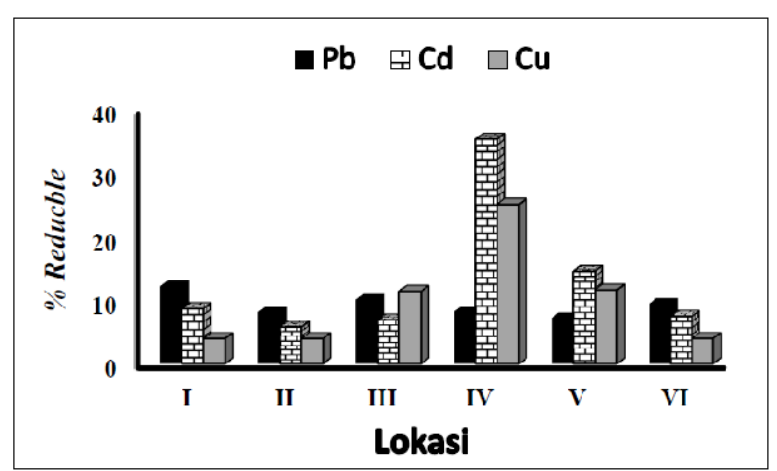

Gambar 3. Fraksi reducible dalam sedimen

Pada tahapan ekstraksi yang ketiga adalah untuk mengekstrak logam berat yang berasosiasi dengan senyawa organik dan/atau senyawa sulfida. Fraksi 3 ini diperoleh dengan mengekstraksi sedimen dengan menggunakan hidrogen peroksida $\left(\mathrm{H}_{2} \mathrm{O}_{2}\right)$ yang merupakan oksidator kuat, dan bertujuan untuk melepaskan 
ikatan - ikatan logam berat yang terikat pada senyawa organik dan sulfida. Fraksi ini sering disebut sebagai fraksi oxidizable karena dapat dioksidasi oleh oksidator kuat. Logam pada fraksi ini merupakan logam yang berpotensi bioavailable dan akan menjadi bioavailable apabila terdapat oksidator kuat yang mengenai sedimen di lingkungan tersebut (Gasparatos dkk. 2005). Kandungan logam $\mathrm{Pb}, \mathrm{Cd}$ dan $\mathrm{Cu}$ yang terekstraksi pada fraksi ini berturut-turut berkisar antara 1,84-7,31\%, 3,56-19,02\%, dan 11,1190,12\% (Gb. 4). Konsentrasi logam $\mathrm{Cu}$ yang terekstraksi pada fraksi ini cukup tinggi. Logam $\mathrm{Cu}$ banyak bersumber dari aktivitas pembakaran yang dilakukan di lokasi 2, yang lokasinya berada pada lingkungan Tempat Pembuangan Akhir Sampah (TPA) yang memiliki kandungan bahan organik yang tinggi. Oleh karena $\mathrm{Cu}$ memiliki afinitas paling besar terhadap bahan organik, maka $\mathrm{Cu}$ terikat paling banyak pada fraksi ini dibandingkan logam lainnya.

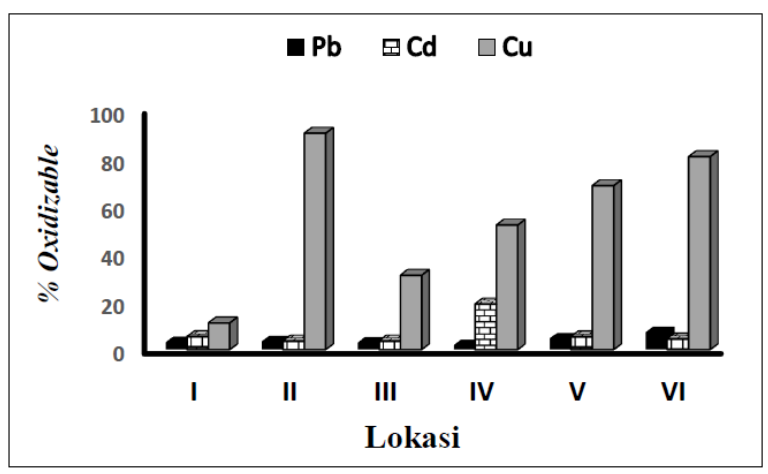

Gambar 4. Fraksi oxidizable dalam sedimen

Oleh karena fraksi reducible dan oxidizable merupakan fraksi dengan kandungan logam berat yang berpotensi bioavailable, maka kedua fraksi ini dijumlah dan digunakan dalam menetapkan jumlah (\%) logam yang berpotensi bioavailable. Dengan demikian, persentase logam $\mathrm{Pb}, \mathrm{Cd}$, dan $\mathrm{Cu}$ yang berpotensi bioavailable berturut-turut $10,05-16,81 \%$; 9,4154,44\%; dan 15,18-94,19\%.

Pada tahapan ekstraksi terakhir adalah untuk menentukan fraksi resistant. Fraksi ini merupakan golongan logam yang memiliki sifat stabil dan terikat kuat dengan mineral primer yang terdapat dalam sedimen. Oleh karena sifatn dari ikatan tersebut, maka fraksi ini disebut sebagai fraksi non bioavailable. Dari ketiga logam yang diteliti, persentase logam yang terekstraksi pada fraksi ini merupakan jumlah yang tertinggi. Logam $\mathrm{Pb}, \mathrm{Cd}$, dan $\mathrm{Cu}$ yang terkekstraksi berturut-turut berkisar antara 79,53$84,22 \%, 25,11-86,04 \%$, dan 1,84-80,67\% (Gb. 4).Keberadaan logam pada fraksi ini tidak perlu dikhawatirkan karena bersifat non bioavailable. Adapun sumber logam pada spesies ini berasal dari cemaran secara alami diantaranya, letusan gunung berapi, pelapukan / penghancuran batuan atau penguraian kristal silikat pada batuan (Yap dkk., 2003).

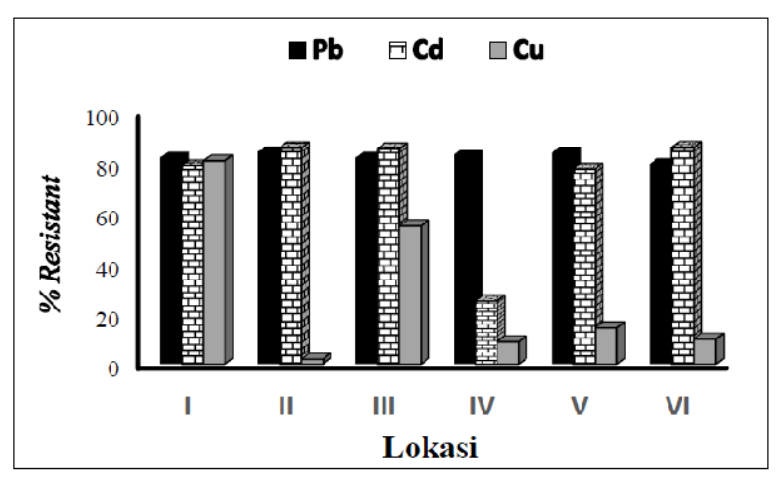

Gambar 5. Fraksi resistant dalam sedimen

Secara umum, pola penyebaran spesiasi logam pada sedimen Sungai Roomo Gresik adalah $\mathrm{F} 4>\mathrm{F} 2>\mathrm{F} 1>\mathrm{F} 3$ untuk logam $\mathrm{Pb}$ dan $\mathrm{Cd}$, sedangkan untuk logam $\mathrm{Cu}$ pola penyebarannya sedikit berbeda F3 > F4 > F2 > F1. Walaupun air dan sedimenSungai Roomo Gresik tergolong tercemar oleh logam $\mathrm{Pb}, \mathrm{Cd}$, dan $\mathrm{Cu}$, tapi dengan melihat pola penyebaran logam tersebut dalam sedimen, maka logam yang bioavailable relatif rendah karena didominasi oleh logam yang non bioavailable ( $\mathrm{Pb}$ dan $\mathrm{Cd}$ ) dan berpotensi bioavailable $(\mathrm{Cu})$. Ini berarti bahwa sumber cemaran $\mathrm{Pb}$ dan $\mathrm{Cd}$ yang terakumulasi dalam sedimen dari aktivitas alam.Pola penyebaran ini sangat berbeda dengan pola penyebaran ke tiga logam tersebut pada tanah pertanian. Seperti yang dilaporkan oleh Siaka et al., 2016, dimana $\mathrm{Pb}, \mathrm{Cd}$, dan $\mathrm{Cu}$ tertinggi terikat pada fraksi reducible (F2) dan terkecil terikat pada fraksi Oxidizable(F3). F4 berada pada posisi ke 3 untuk $\mathrm{Pb}$ dan ke 2 untuk $\mathrm{Cd}$ dan Cu.Ini menunjukkan bahwa, sumber pencemar logam berat pada tanah pertanian sebagian besar berasal dari aktivitas manuasia terutama aktivitas pertanian.

\section{SIMPULAN}

Dari hasil penelitian ini, dapat disimpulkan bahwa, kandungan rata - rata logam berat $\mathrm{Pb}, \mathrm{Cd}$ dan $\mathrm{Cu}$ total berturut-turut 1,6038 - 
7,8365 mg/L; 0,0251 - 0,0798 mg/L; dan 0,1709 - 0,2249 mg/L dalam air sungai, 213,7750 $539,0763 \mathrm{mg} / \mathrm{kg} ; 3,3467$ - 39,7071 mg/kg; dan $36,9168-190,7079 \mathrm{mg} / \mathrm{kg}$ dalam sedimen. Air sungai dan sedimen di aliran Sungai Roomo telah tercemar oleh $\mathrm{Pb}, \mathrm{Cd}$ dan $\mathrm{Cu}$.

Spesiasi logam $\mathrm{Pb}, \mathrm{Cd}$, dan $\mathrm{Cu}$ dalam sedimen Sungai Roomo Gresik didominasi oleh spesies resistant dan yang terkecil adalah spesies EFLE untuk logam $\mathrm{Cu}$ dan spesies oxidizable untuk logam $\mathrm{Pb}$ dan $\mathrm{Cd}$ dengan urutan $\mathrm{F} 4>\mathrm{F} 2>$ $\mathrm{F} 1>\mathrm{F} 3$ untuk $\mathrm{Pb}$ dan $\mathrm{Cd}$, sedangkan untuk $\mathrm{Cu}$ adalah $\mathrm{F} 3>\mathrm{F} 4>\mathrm{F} 2>\mathrm{F} 1$.

Logam $\mathrm{Pb}, \mathrm{Cd}$ dan $\mathrm{Cu}$ yang bioavailable berturut - turut $2,78-7,11 \% ; 1,98-20,44 \%$; dan $2,49-13,66 \%$, sementara yang berpotensi bioavailable adalah $10,05-16,81 \%$ untuk $\mathrm{Pb}$; 9,41-54,44\% untuk Cd; dan 15,18-94,19\% untuk $\mathrm{Cu}$. Logam $\mathrm{Pb}, \mathrm{Cd}$ dan $\mathrm{Cu}$ yang non bioavailable berturut-turut $79,53-84,22 \% ; 25,11-86,04 \%$; dan $1,84-80,67 \%$.

\section{DAFTAR PUSTAKA}

Australian and New Zealand Environment and Conservation Council (ANZECC). 2000. ANZECC Interim Sediment Quality Guidelines, Report for the environmental research institute of the supervising scientist, Sydney.

Bernard, T. and Neff, J. 2001. Metals Bioavailability in the Navy's Tiered Ecological Risk Assesment Process, Issue Paper, Washington Navy Yard, page 1-15.

Damanhuri, E.,dan Tri, P. 2010. Diktat Kuliah Pengelolaan Sampah. Institut Teknologi Bandung, Bandung.

Darmono. 1995. Logam Dalam Sistem Biologi Makhluk Hidup. Universitas Indonesia Press, Jakarta.

Fajri, N. E. 2001. Analisis Kandungan Logam Berat $\mathrm{Hg}, \mathrm{Cd}$, dan Pb Dalam Air Laut, Sedimen, dan Tiram (Carassostrea cucullata) di Perairan Pesisir Kecamatan Peder Kabupaten Karawang Jawa Barat. Tesis. Fakultas Pascasarjana IPB, Bogor.

Gasparatos, D., Haidouti, C., Andrinopoulus and Areta, O. 2005. Chemical Speciation and Bioavailability of $\mathrm{Cu}, \mathrm{Zn}$, and $\mathrm{Pb}$ in Soil from The National Garden of Athens, Greece, Proceedings: International Conference on Environmental Science and Technology, Rhodes Island.

Lu, F. C. 1995. Toksikologi Dasar UI Press: Jakarta.

Ma'ruf. 2007. Adaptasi Konsentrasi Logam Berat pada Ikan Baronang (Siganus sp) dan Lingkungan Perairan untuk Pengolahan Wilayah Pesisisr Bontang. Tesis. Universitas Mulawarman.

Pascoli, C. 1999. Nature Waters and Water Technology. Italy.

Siaka, M., C. M. Owens, G. F. Birch. 1998. Evaluation of Some Digestion Methods for The Determination of Heavy Metal in Sediment Samples by Flame-AAS, Analytical Letters. 31(4):703-718.

Siaka, I M., Utama, I M.S., Manuaba, I. B. P, and Adnyana, I M. 2016. Speciation and Bioavailability of Some Heavy Metals in Agricultural Soils Used for Cultivating Various Vegetables in Bedugul, Bali. AIP Conference Proceedings: $\quad 5^{\text {th }} \quad$ International Conference and Workshop on Basic and Applied Sciences (ICOWOBAS 2015). 1718 pp. 050005-1-050005-11.

Suryati. 2011. Analisa Kandungan Logam Pb dan $\mathrm{Cu}$ dengan Metode Spektrofotometri Serapan Atom Terhadap Ikan Baung (Hemibagrus nemurus) di Sungai Kampar Kanan Desa Muara Takus Kecamatan XIII Koto Kampar Kabupaten Kampar, Jurnal Ilmiah Mahasiswa UIN Sultan Syarif Kasim Riau, 10(3): 23-31.

Yap, C.K., Ismail, A., dan Tan, S.G., 2003, Concentration, Distribution and Geochemical Speciation of Copper in Surface Sediment of the Strait of Malacca, Pakistan Journal of Biological Science, 6(12): 1021-1026.

Zulfitri. 1998. Pemanfaatan Mikroorganisme Sebagai Salah Satu Alternatif Pengolahan Limbah Industri, Jurnal Lingkungan dan Pembangunan, Pusat Studi Lingkungan Perguruan Tinggi Seluruh Indonesia: Jakarta. 